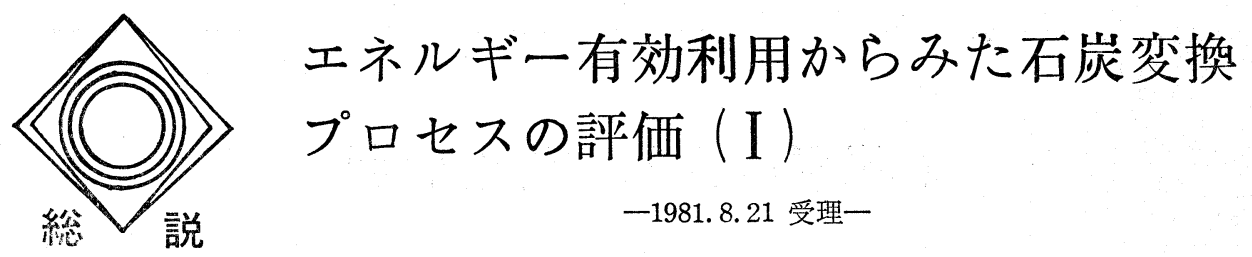

$\begin{array}{llll}\text { 東京理科大学 } & \text { 西 } \text { 田 直 } \begin{array}{l}\text { 矩* } \\ \text { 東京工業大学 } \\ \text { 石 } \text { 田 }\end{array} \text { 愈** }\end{array}$

\section{1. はじめに}

WAES (Workshop on Alternative Energy Strategies)のレポートによれば, 石油需給ギャップが生ず る時期を昭和60年(1985年) 75年 (2000年) と予測して おり，この時期を “エネルギーの谷間” と称して，こ の谷間を乗り切り需給ギャップを埋める上で, 原子力 とともに石炭エネルギーに対して重要な役割が課せら れている。

石炭資源は豊富に存在するとはい光，そのままでは 固体であることによる取り扱いの不便さ，環境への影 響などで大々的に利用することはできない。そこで， 電力あるいは，使いやすいクリーンな燃料であるガス 体あるいは液体のエネルギーに変換することによって 利用することになる。変換にあたっては必ずェネルギ 一のロスが生ずる。

4 回にわたる本総説の目的は，エネルギー有效利用 の立場から，石炭ガス化，液化などの個々の具体的な 石炭変換プロセスを評価するとともにトータルシステ ムとしての石炭転換技術の位置付けを明確にするとこ ろにある。

今回は, はじめに, エネルギー変換に打ける効率の 考兄方を熱力学的な立場から概説する。つぎに, 二次 エネルギーの最終利用形態として加熱用と動力用を取 り上げ，種々のエネルギー変換プロセスの中で一次エ ネルギーが最終的にどのように利用されるかを，エネ ルギーの総合効率の面から考察する。また，わが国化 打いて, 将来石炭エネルギーが大々的に利用されるに あたっては，現状に拈けるわが国のエネルギー消費構 造を把握する必要があるところから，わが国に和ける エネルギーの消費構造をエネルギーの流れとして米国 の場合と対比して分析する。最後に，わが国のエネル ギー消費構造の中で石炭変換プロセスがぞのように位

* 工学部経営工学科 東京都新宿区神楽坂 1-3 ** 資源化学研究所 横浜市緑区長津田町 4259
置付けられるかを概説する。

な拉，次回以後予定している内容は以下のようであ る。

2 回目 : エネルギー評価の方法拈よび石炭の燃焼効 率

3 回目 : 石炭液化プロセスのエネルギー利用效率

4 回目 : 石炭ガス化プロセスのエネルギー利用効率 物よび石炭転換プロセスのトータルシステ ムとしての位置付け

\section{2. エネルギー変換勃率}

エネルギー変換システムに和けるエネルギーの利用 状況を把握するための定量的な尺度としてシステムの 変換効率がある。一次ェネルギーとしては化石燃料を はじめ多くの資源があるが，それを直接，最終需要エ ネルギーとして利用することは困難である(薪などの 例外はあるが)。従って, 一次エネルギーを最終需要 に適した形態に変換しなければならない。場合によっ ては，2段階以上の変換を経て最終需要エネルギーの 形態となることもあろう。別の形態のエネルギーに恋 換するためには，一般に自分自身のエネルギーの一部 を利用するか，外部からエネルギーを供給することに なる。そのため, 変換前に持っていたエネルギー（外 部から供給したェネルギーも合わせて）と，変換によ って得られた有用なエネルギーを定量的に比較した場 合, 後者の方が小さくなる。その減少の度合を定量的 に表現したのが効率である。エネルギー変換システム の効率には, 熱力学第一法則に基づく効率と熱力学第 二法則飞基づく効率がある。

エネルギー変換システムの評価の方法については次 回詳しく論ずるので，ここでは本稿を理解する上で必 要最小限の記述にとどめる。な扮熱力学第二法則に基 ら゙くエネルギーシステム解析一般については幾つかの

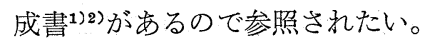

従来, 一般に使われてきた効率は熱力学第一法則に 甚づくもので, 通常, 熱効率と呼ばれ以下のように定 
義される。

$$
\eta_{1}=\frac{P_{E, p}}{P_{E, f}}
$$

$\mathrm{P}_{\mathrm{E}, \mathrm{p}}$ はエネルギー変換によって得られる使用目的 に応じた形態のエネルギー (useful energy), $\mathrm{P}_{\mathrm{E}, \mathrm{f}}$ は 投入されたエネルギーでエエンタルピーで表わす。

一方, 熱力学第二法則に基らく効率は以下のように 定義される。

$$
\eta_{\mathbb{I I}}=\frac{\mathrm{P}_{\mathrm{A}, \mathrm{p}}}{\mathrm{P}_{\mathrm{A}, \mathrm{f}}}
$$

$\mathrm{P}_{\mathrm{A}, \mathrm{p}}$ は出力有用エクセルギー (useful exergy), $\mathrm{P}_{\mathrm{A}, \mathrm{f}}$ は入力エクセルギーである。エクセルギーは, 有 効エネルギー (available energy) と呼ばれることもあ る。

有効エネルギーの概念は, 最初に Gibbs ${ }^{3)}$ によて 提出され，今世紀になって Keenan ${ }^{4}$, 最近では Gaggioli5) らによってその実用的な利用が紹介された。あ る系のエクセルギーとは，与えられた環境条件の下 で，その系を可逆過程を経て安定な外界と平衡な状態 に移すまでに, その系から取り出し得る最大の仕事量 と定義される。外界と平衡な状態とは外界と圧力, 温 度が等しく, かつ外界の組成と等しい状態をいら。通 常, 外界の状態については, 外気条件とする。従っ て，一般には外界の組成としては空気および水を参照

\section{表 1 エネルギー変換システムの}

\begin{tabular}{|c|c|c|}
\hline $\begin{array}{l}\text { エネルギー } \\
\text { 変換システム }\end{array}$ & 熱效 & $\begin{array}{c}\text { エクセル } \\
\text { ギ一効率 } \\
\eta_{\text {II }}\end{array}$ \\
\hline 大型発電機 & $0.99 \sim 0.96$ & 0.98 \\
\hline 水力タービン & $0.93 \sim 0.80$ & 0.90 \\
\hline 大型モーター & $0.95 \sim 0.85$ & 0.90 \\
\hline 小型モーター & $0.85 \sim 0.75$ & 0.70 \\
\hline 蓄 電 池 & $0.90 \sim 0.75$ & 0.80 \\
\hline 大型ボイラー & $0.92 \sim 0.88$ & 0.49 \\
\hline ディーゼルエンジン & $0.44 \sim 0.30$ & 0.36 \\
\hline 家庭用ガスレンジ & $0.85 \sim 0.60$ & 0.13 \\
\hline 自動車エンジン & $0.30 \sim 0.17$ & 0.25 \\
\hline スチーム発電プラント & $0.42 \sim 0.33$ & 0.36 \\
\hline 家庭用電気温水器 & 0.93 & 0.16 \\
\hline 家庭用ガス温水器 & $0.70 \sim 0.30$ & 0.12 \\
\hline 家庭用電気乾燥器 & 0.50 & 0.095 \\
\hline 家庭用電気ヒートポンプ & - & 0.60 \\
\hline 家庭用電気冷蔵庫 & - & 0.096 \\
\hline クーラー & - & 0.17 \\
\hline 白 熱 灯 & 0.05 & 0.048 \\
\hline 鳤 光 灯 & 0.20 & 0.195 \\
\hline
\end{tabular}

$$
\eta_{\mathrm{I}} \text { と } \eta_{\text {II }} \text { の值 }{ }^{6)}
$$

する。

熱力学第一法則に基づく場合も第二法則に基つく場 合も, エネルギーの単位は通常, $\mathrm{kcal}$ や $\mathrm{J}$ で表示され る。しかし, 等しい熱量を有する系でも, その温度, 圧力, 組成などが異なればェクセルギーは異なる。た とえば同じ熱量 (エンタルピー) をもつ40ㄷの水と500 ${ }^{\circ} \mathrm{C}$ の蒸気を比較した場合, $40^{\circ} \mathrm{C}$ の水は外界の状態に近 いのでたとえその量が多くても，エクセルギーは 500 ${ }^{\circ} \mathrm{C}$ 蒸気より小さく価值の小さいエネルギーである。

以上の理由から, 熱力学第二法則に基づく効率はエ ネルギーの利用状況を表わす真の尺度であるのに対し て, 熱力学第一法則に基づく効率, いわゆる熱効率は その近似の尺度でしかない。

表 1 は各種エネルギー変换機器および装置の熱効率

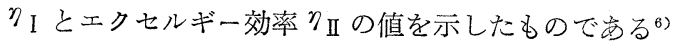
7)。発電機, 水力タービン, 電気モータでは, 投入さ れたエネルギー（有効エネルギー）が, ほぼ全量, 有 効な仕事として出力されるためにク I 1 に近い值となっている。一方，化石然料然焼による 大型ボイラー, 家庭用ガスレンジ, 電気温水器, ガス 温水器, 電気乾燥器では, $\eta_{\text {II }}$ の值は, $\eta_{\mathrm{I}}$ の值に比較 して非常に小さい。この理由は, これらの機器あるい は装置に対して投入されたエネルギーがほぼ全量利用 される反面, 発生されたエネルギーが急激な温度勾配 での熱移動によって伝えられるために, 不可逆過程で 有効エネルギーを失い, 実際に有効に使われるエネル ギーが少なくなるためである。これらの機器の中で も，低い温度を生成する(たとえば70足の温水を沸す) ための家庭用加熱機器のエクセルギー効率は非常に小 さく, 機器の効率改善の余地が残されていると言えよ ら。な和表 1 に示されている数值, 特に加熱用機器の クII 值は機器の利用温度, 外界の環境条件の設定の仕 方で異なるので絶対的な值ではない。

\section{3. 機能別鼠終需要エネルギーの生産}

エネルギーの需要は，エネルギーを必要とするニ一 ズ，すなわち最終需要といら形で発生する。その需要 を満たすためには, 一次エネルギーを順次適切に变換 し，最終需要に適した形態で供給しなければならな い。最終的に使用される形態は, その機能によって, 熱, 動力, 照明に分類される。同じ機能形態を持つエ ネルギーを生産する変換プロセスのフローの数は，た と光同じ一次エネルギーから出発しても多数考学られ る。

3.1 加熱用エネルギーの生産プロセス

図1は，加熱用エネルギーを生産するためのエネル 


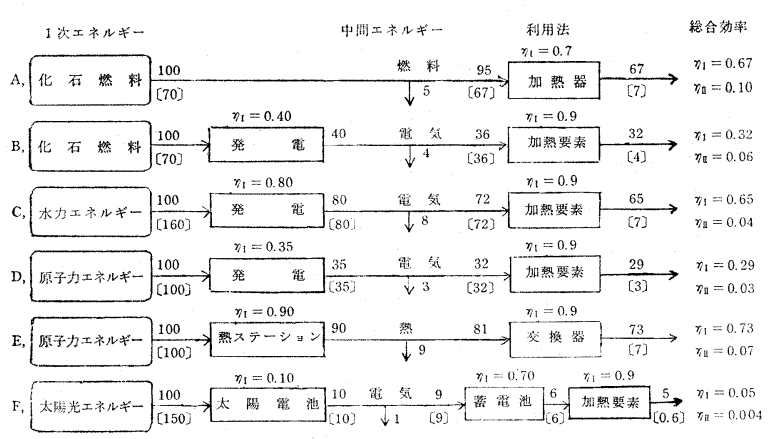

図 1 加熱用エネルギー生産のためのエネルギー 変換プロセスの例

ギ一変換プロセスの例である ${ }^{8)}$ 。 線上の数值はエンタ ルピーに基う゚く適当な単位で表わされている。また [ ]内の数值は, 熱力学第二法則に基づく有効エネル ギーまたはエクセルギーの適当な単位で表わされてい る。また中間エネルギーの輸送ロス，送電ロスなどを 下向きの矢印の右横に示してある。エクセルギー 值 は，外界の温度を $5{ }^{\circ} \mathrm{C}$ とて計算されている。また， 最終需要に扣ける加熱器（たと壳ば石油コンロ）, 加 熱要素（電気温水器など）および熱交換器では, 家庭 用の温水を沸かすと仮定してその利用温度を $70^{\circ} \mathrm{C}$ と て計算を行っている。

Aのケースは化石燃料を適当な精䡛処理を行った 後, バーナーなどで然焼させ温水を得る場合で, 総合 熱効率 $\eta_{\mathrm{I}}$ は0.67となっている。一方，有效エネルギ 一に基づく総合効率は 0.10 となっている。Bのケース は化石然料を火力発電によって電気に変撸し, 最終プ ロセスで電気温水器などで加熱する場合で, 総合効率 ク I， 政はそれぞれ0.32，0.06となっている。Bのケ 一スはAのケースと同じく化石然料を一次ェネルギー としているが，総合熱効率 ク I はAのケースの約 2 分 の 1 である。熱力学第一法則に基づてて効率を評価す る限り Bのケースは良くないと言える。しかし，熱力 学第二法則に基ついて総合効率を評価するかぎり，両 ケースとも $90 \%$ 以上のエクセルギーが使われずに廃棄 されたことになり，両ケースとも実質的な改善の余地 が残されている。

一次エネルギーを水力エネルギーとしたケースCで

* 原著では加熱要素の効率 ク I が 1.0 となっている が，ここでは 0.9 とした。ぬた一次エネルギーの エクセルギーの計算法については，いまだ統一さ れていないこともあって，原著と後で紹介する

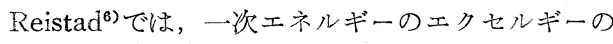
評洒が異なる。
は, Bのケースと同様, 中間エネルギーを電 気としているが, 水力発電に打ける水力タ一 ビンの効率 ク I が良いために，Bのケースの 総合熱効率 $\eta_{\mathrm{I}}$ の約 2 倍となっている。

ケースDとEは原子力エネルギー(核分裂) を一次ェネルギーとした場合である。この場 合も, 中間エネルギーとして電気に変換した 場合, 総合熱効率 ク I は熱として利用する場 合の半分以下になっている。ただし, 熱とし て最終需要で利用することは現時点では不可 能であるが，理論上の計算例として示してあ る。

ケース Fは太陽光エネルギーを太陽電池によって電 気に変換する現在開発中の新エネルギー技術の例であ る。総合効率 $\eta_{\mathrm{I}}, \eta_{\text {II }}$ 共にきわめて悪いことがわか る。

このように最終需要においてエネルギーが加熱用に利 用される場合, 一般に中間エネルギーを電気として変 換するよりも，一次エネルギーを適当に処理したのち 然料として然焼させて熱そ取り出した方が総合熱効率 は格段に良いことがわかる。しかし，エクセルギーで 見るかぎり，いずれのケースでも $90 \%$ 以上の有効エネ ルギーが廃棄されて拉り, 変換プロセスの質的な改善 が必要である。その改善の余地は主として家庭用加熱 機器にある。それは工業用の加熱装置についても同様 である。工業用の装置では利用温度が高いので, 有効 エネルギーに基つく效率はやや高いが，それでも総合 効率は高々 $0.2 \sim 0.3$ (利用温度 $300^{\circ} \mathrm{C}$ の場合) 程度で ある。

\section{2 動力用エネルギーの生産プロセス}

つぎに, 最終需要として動力あるいは機械的仕事の 形態でェネルギーを必要とする場合のエネルギー変換 のプロセスを考える。この形態は主として自動車, 鉄 道などの輸送機関で利用される。

まずはじめに，動力生産のための各種エネルギー変 換システムの熱効率 $\eta_{I}$ とエクセルギー効率 $\eta_{I I}$ を表 1 で比べてみると，ほとんど両者は等しいことがわか る。この点は, 加熱用変換装置と大きく異なってい る。従って, 以下に動力生産のためのエネルギー変換

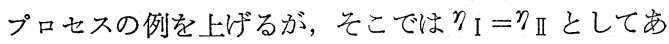
る。ただし，一次ェネルギーのエンタルピーとエクセ ルギー值は一般に異なるのですべての変換過程で動力 を利用したとしても両者の総合効率は一致しない。

図 2 は動力あるいは機械的仕事生産のためのエネル ギー変換プロセスの例である ${ }^{8)}$ 。Aのケースは，適当 


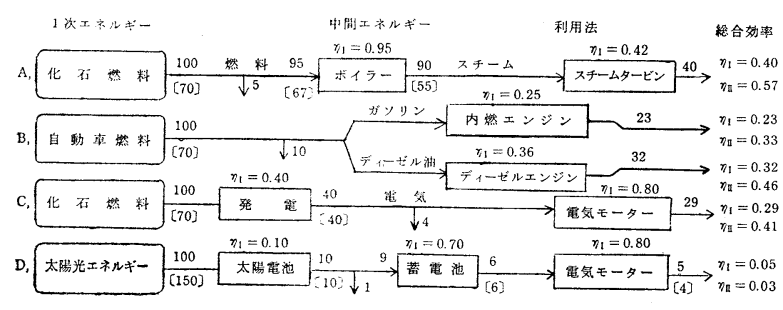

図 2 動力生産のためのエネルギー変換プロセスの例
に精製した化石然料をボイラーで燃焼しスチームを発 生しそれによってタービンを動かす場合である。スチ 一ムタービンのかわりに効率の悪いスチームエンジン $\left(\eta_{\mathrm{I}}=\eta_{\mathbb{I}}=0.10\right)$ を用いると総合效率 $\eta_{\mathrm{I}}, \eta_{\mathbb{I}}$ はそれ ぞれ0.09，0.13となる。

Bのケースは自動車の動力として利用する場合であ る。熱力学第一法則に基つくく総合効率 $\eta_{\mathrm{I}}$ は $0.23,0.32$ と低い。これは自動車エンジンの効率の悪さに直接帰 因している。省エネルギー型の輸送システムの開発が 望まれる。Cのケースは電気モーターを利用する場合 のエネルギー変換プロセスである。Bのケースと同 様, 一次エネルギーは化石然料である。総合効率 $\eta_{\mathrm{I}}$ および ク II はBの場合と同程度であり, 效率の良い電 気モーターを利用しているにもかかわらず総合効率が 低いのは火力発電の低効率に帰因している。從って, 化石然料を一次エネルギーとしてBのケースと比較す る限り, 電気自動車 (この場合, 蓄電池を必要とする ので総合効率はさらに低下する) の利用によって一次 エネルギーの節約は期待できない。

Dは太陽光エネルギーを太陽電池によって電気に変 換し電気モーターを動かす場合である。総合効率は太 陽電池の効率の悪いことから非常に低い。

熱力学第一法則に基つく動力生産のための総合効率 は, 太陽光ェネルギーの場合を除いて0.23〜0.40の範 囲にあり，加熱用エネルギー生産の総合効率の平均よ りもやや低い程度である。乙かし熱力学第二法則の効 率ではそれが逆転している。従って, 一次エネルギー の実質的な有効利用に和いては動力生産の変換プロセ スの方がェネルギーの利用効率が良いことがわかる。

本節では，エネルギー最終需要に打ける形態の中で 最も多く利用されている熱と動力について, それらを 生産するためのエネルギー变換プロセスを種々の一次 エネルギーを起点とした例を上げ，熱力学第一法則特 よび第 2 法則に基づく総合効率を比較した。それによ れば，第一法則に基づく熱効率では熱生産のための変 換プロセスの方が動力生産のためのプロセスに比較し
て平均的に高いが, エクセルギーの利用効率 の点では, それが逆になっており, 特に熱生 産の総合効率がきわめて低く, 一次エネルギ 一の有効エネルギーの80～90\%が廃棄されて いることが指摘された。実質的な一次エネル ギーの有効な利用方法は, 有効エネルギーに 基づいて評価されるべきであるので, 熱生産 のための変換プロセスについて, 単位変換機 器の効率の改善のみならず, トータルシステ 么的な検討が必要であろら。

ここでは, エネルギーの変換効率のみで比較した が, 実際には経済性, 安全性, 環境への影響などを考 慮して評価すべきであることは言らまでもない。

\section{4. エネルギーの消費構造}

\section{1 世界のエネルギー消費構造}

本節では, はじめにエネルギーの効率的使い方につ いて, 熱力学第一法則に基づく熱効率の面から歴史的 に振り返ってみる。産業革命以前の主要なエネルギー は木材和よび石炭であり, その利用形態はほとんどが 家庭に和ける暖房と調理用の熱であった。その効率が 墨かったことは言うまでもない。その後, 調理器具の 改善がなされ効率が向上したが, 一方で, 産業の発達 と共に種々の熱機関が出現したが，それらの効率が悪 いため, エネルギーの損失が増大した。その後, 装置 の改善によって効率が良くなったが，自動車の普及に よって，その損失は再び増大した（自動車のエンジン の効率は $0.2 \sim 0.3)$ 。それに平行して, 効率のよい水 力発電の利用, エネルギー変換機器の効率の改善がな されたが，その効率の向上を相殺するよらにェネルギ 一損失の大きい火力発電が多用されるよらになったた めに, 先進諸国では1950年頃から総合熱効率は横ばい になっている。しかし, 将来電力の需要が増加するこ とが予想されるので, むしろ総合熱効率は低下するで あろう。な和参考までに, スイスについて国レベルで の総合熱効率の経年変化を試算した結果 ${ }^{8)}$ があるので 以下に示吉。

$$
\begin{aligned}
& \text { 1910年 } \eta_{\mathrm{I}}=0.38 \\
& 1930 \text { 年 } \eta_{I}=0.49 \\
& 1950 \text { 年 } \eta_{I}=0.51 \\
& \text { 1960年 } \eta_{\mathrm{I}}=0.53 \\
& \text { 1970年 } \eta_{\mathrm{I}}=0.52
\end{aligned}
$$

1955年のジュネーブにおける原子力に関する会議 で，1952年に拈ける世界規模での一次エネルギーの消 費量および有用なエネルギーの生産量が試算された結 果が報告された。それによると一次エネルギーの消費 
量 $104 \mathrm{EJ}\left(=104 \times 10^{18} \mathrm{~J}\right)$ 飞対して有用エネルギーの生 産量は $37 \mathrm{EJ}\left(=37 \times 10^{18} \mathrm{~J}\right)$ であったから，当時の世界

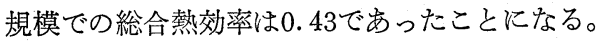

エネルギーに関する世界的規模の調査の最近のもの としてWAESの報告9がある。1972年に和ける共産圈 を除く自由世界の一次ェネルギー消費量は $176 \mathrm{EJ}$ (= $176 \times 10^{18} \mathrm{~J}$ =石油換 算 8,100 万バーレル/日）で各部門 別エネルギー需要技よび転換口スは以下のようであ る。

\section{民生部門等 $34.8 \mathrm{EJ}$}

運輸部門 $33.4 \mathrm{EJ}$

鉱工業部門 $46.6 \mathrm{EJ}$

原料 $9.5 \mathrm{EJ}$

転換口ス $51.9 \mathrm{EJ}$

最終需要に乱変換効率が明らかにされていない ので有用なエネルギーの生産量は不明であるが，仮 に, 後で紹介する米国 (1970年) 括よび日本（1975年） の各最終需要部門に和ける変換効率の平均値（民生部 門等 : 0.8 , 運輸部門 : 0.22 , 鉱工業部門 : 0.78）を 適用してみると有用エネルギーの生産量は原料子含め て $81 \mathrm{EJ}$ となる。従って, 総合熱効率は 0.46 となる。

エンタルピー基準で一次エネルギーの約50〜 $60 \%$ が 有用なエネルギーとして利用されることなく変換口ス として毎年廃棄されていることになる。な赫, 熱力学 第二法則に基づく有効ェネルギーについての世界的規 模の調查はない。

\section{2 日本特よび米国のエネルギー消費構造}

次にわが国特よび米国に和けるエネルギーの供給と 消費の状況について比較してみる。図 3 は1975年に和 ける一次エネルギーから最終需要消費にいたるエネル

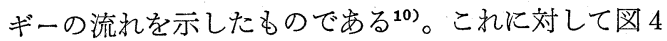
は1970年に打故米国のエネルギーの流れを示したも

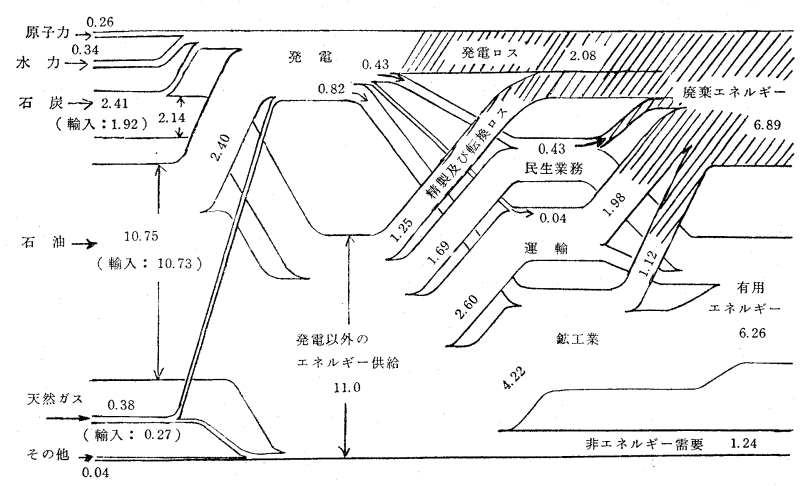

図 3 わが国におけるエネルギーの流れ $(1975 \text { 年 })^{10)}$ (単位 : $10^{15} \mathrm{Btu}$ )

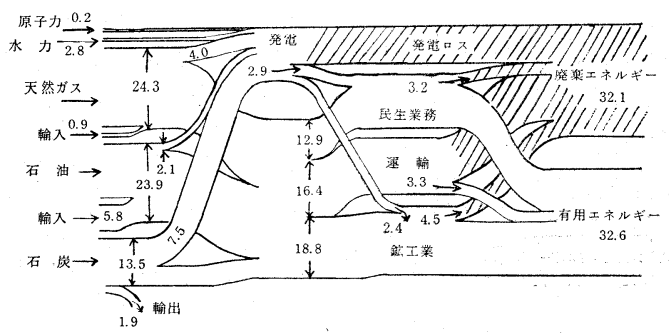

図 4 米国におけるエネルギーの流れ (1970年) $)^{7)}$ (単位 : $10^{15} \mathrm{Btu}$ )

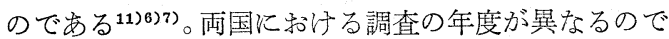
厳密な比較はできないが，両国淿和けるエネルギー消 費構造の特徵と相違点については把握できるであろ う。

一次エネルギーの供給構成について見てみると,わ が国の一次エネルギーに占める石油の量が他のエネル ギーに比べて非常に大きいことがわかる。米国活い ては, 天然ガスが石油と注涪同率で一次エネルギーを 構成して招り，天然ガスと石油を合わせて全体の $74 \%$ を供給している。な称現在では，天然ガスの供給比率 が石油に比較して低くなっている。一次エネルギーの らち発電によって消費される比率は両国ともほぼ等し く約 $25 \%$ である

両国のエネルギー消費の相違は, 最終需要に和ける 部門別エネルギー消費の構成比によくあらわれてい る。わが国特よび米国に拈ける最終需要エネルギーの 部門別構成比は以下のようである。

$\begin{array}{lll} & \text { 日本 } & \text { 米国 } \\ \text { 民生業務部門 } & 22 \% & 30 \% \\ \text { 運 輸 部 門 } & 27 \% & 31 \% \\ \text { 鉣工業部門 } & 51 \% & 40 \%\end{array}$

わが国活いては，鉱工業部門，米国に㫟いては民 生業務部門和よび運輸部門の消費量が非常 に大きいことがわかる。な称わが国化执い ては，鉱工業部門に和ける消費エネルギー のらち, 鉄鋼と化学で約 6 割を占めてい る。

つぎに，一次ェネルギーのららどれだけ 最終的に有用なエネルギーとして使われた かを見てみる。わが国の場合，一次エネル ギーの供給量 $14.18 \times 10^{15} \mathrm{Btu}(=354.6 \times$ $10^{13} \mathrm{kcal}$ ) 飞対して, 有用エネルギーは, 非エネルギー需要も含めて $7.5 \times 10^{15} \mathrm{Btu}$ $\left(=187.5 \times 10^{13} \mathrm{kcal}\right)$ で, 総合熱効率は53 \%となる。米国の場合は， $63.8 \times 10^{15} \mathrm{Btu}$ 


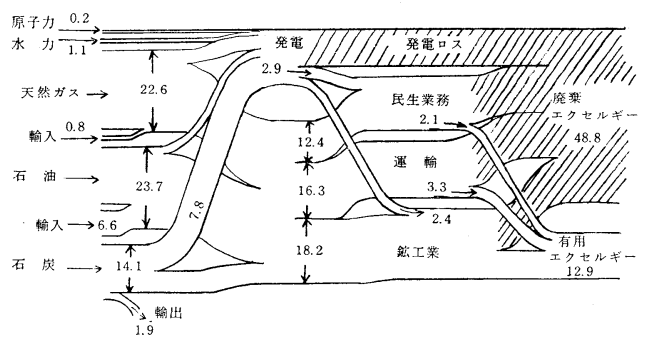

図 5 米国におけるエクセルギーの流れ $(1970 \text { 年 })^{7)}$ (単位 : $10^{15} \mathrm{Btu}$ )

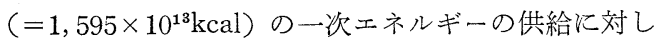
て, 有用エネルギーは $32.6 \times 10^{15} \mathrm{Btu}\left(=815 \times 10^{13}\right.$. $\mathrm{kcal})$ で，総合熱効率は51\%である。両国とも一次エ ネルギーの持っていた熱量のらら約半分を廃棄エネル ギーとしてロスしたことになる。なお，この総合熱効 率は WAES のデータをもとに試算した世界の1972年 における総合熱効率46\%よりもやや高くなっている。

ところで Reistad (2) は, 図 4 の1970年に和ける米国 のエネルギーフローに対して, 熱力学第二法則に基づ いて有効エネルギーの計算を行った。図 $5^{7)}$ は, その 結果をエクセルギーの流れで表わしたものである。図 4 と同じ形式で描いてめるので, 両者の相違がよくわ かる。

エネルギーの流れ図では, 有用エネルギーの一単位 を取り出すのに約一単位のエネルギーを失っているの がわかる。一方, 図 5 のエクセルギーの流れ図では, 実際に仕事として使われる有効エネルギーの一単位を 生産するのに, 有効エネルギー約 4 単位が失われてい ることがわかる。ちなみに，熱力学第二法則に基つくく 総合効率は0.21である。図 4 で指摘されるより以上の エネルギー変換技術の改善の余地があることが図 5 に よってわかる。

図4のエネルギーの流れ困では，発電および運輸部 門に和忷る損先が最も大きく，両者は鉣工業和よび民 生業務部門よりもかなり効率悪くエネルギーが消費さ

表 2 米国の1970年におけるエネルギー消費 部門における総括熱効率および総括エ クセルギー効率

\begin{tabular}{|c|c|c|c|c|}
\hline \multicolumn{3}{|c|}{$\begin{array}{l}\text { エネルギー } \\
\text { 消費部門 }\end{array}$} & \multirow{2}{*}{$\frac{\text { 総括熱効率 }}{0.32}$} & \multirow{2}{*}{$\frac{\begin{array}{c}\text { 総括エクセ } \\
\text { ルギー効率 }\end{array}}{0.35}$} \\
\hline 発 & & 電 & & \\
\hline 民 & 生 業 & 務 & 0.797 & 0.137 \\
\hline 運 & & 輸 & 0.201 & 0.20 \\
\hline 鉱 & 工 & 業 & 0.788 & 0.36 \\
\hline
\end{tabular}

表 3 わが国の1975年におけるエネルギー消 費部門における総括熱効率および総括 エクセルギー勃率

\begin{tabular}{|c|c|c|c|}
\hline \multicolumn{2}{|c|}{$\begin{array}{l}\text { エネルギー } \\
\text { 消費部門 }\end{array}$} & \multirow{2}{*}{$\frac{\text { 総括熱効率 }}{0.383}$} & \multirow{2}{*}{$\begin{array}{c}\begin{array}{c}\text { 総括エクセ } \\
\text { ルギー効率 }\end{array} \\
0.334\end{array}$} \\
\hline 発 & 電 & & \\
\hline 民 生 業 & 務 & 0.797 & 0.196 \\
\hline 運 & 輸 & 0.250 & 0.270 \\
\hline 鉱 & 業 & 0.777 & $(0.36)$ \\
\hline
\end{tabular}

れていることがわかる。しかし，図５のエクセルギー の流れ図では, これら4つの部門に拈ける有效エネル ギーの損失は量的には鉣工業がやや少ない以外はほぼ 同程度であることがわかる。表 2 は，4 部門に稍ける熱 力学第一法則および第二法則に基づく総括効率を比較 したものである。熱力学第一法則に基づく総括熱効率 では最も高かった民生業務部門が総括エクセルギー効 率ではきわめて低くなり 4 部門中最低になっている。 これは，3章で述べたよらに家庭で使われる調理用， 温水用および冷暖房用のエネルギー変換機器のエクセ ルギー効率の低さに帰因している。

わが国に拈けるエクセルギーの流れ図については， 現時点で入手できなかったので，Reistad の文献故を 参考に作成してみた。以下簡単にその計算の根拠につ いて述べて沶く。

発電部門については, Reistad と同様に, 原子力発 電, 水力発電のエクセルギー効率をそれぞれ，0.31， 0.79 , 石油などの化石然料による火力発電のエクセル ギー効率を 0.316 と仮定した。次に発電部門の総括エ クセルギー効率を各発電方式に供給される一次エネル ギーの構成比率から求めた。

民生部門については，エネルギー種類別（電気，石 炭, 灯油, 都市ガスなど) の消費構成比率, 用途別 (暖 冷房, 動力, 給湯, 㕌房, 照明など）エネルギー消費 構成比率から表 1 の各種家庭用エネルギー変換システ ムのエクセルギー效率を使って総括エクセルギー効率 を求めた。な敃業務部門に就将るエネルギー種類別, 用途別消費のデーターが手に大らなかったので，民生 部門の総括エクセルギー効率を用いた。

運輸部門については, 各種翰送機関（鉄道，バス・ トラック, 乗用車, 飛行機, 船船) に対するエネルギ 一消費構成比率と, 各輸送機関のエクセルギ一効率 （鉄道：0.70*, バス・トラック：0.25, 乗用車：0.15,

* 推定 


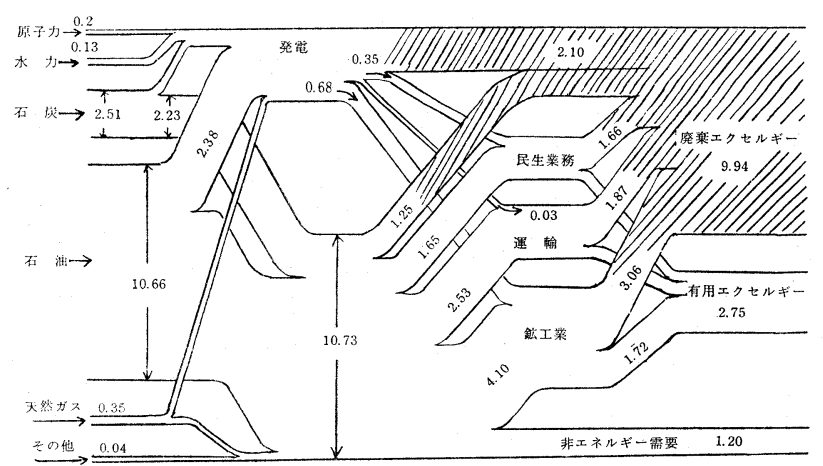

図 6 わが国におけるエクセルギーの流れ（1975年） (単位 : $10^{15} \mathrm{Btu}$ )

表 4 代表的な工業プロセスのエクセルギー 効率
工業プロセス エクセルギー効率

\begin{tabular}{|c|c|}
\hline 鉄 & 0.21 \\
\hline 石 油 精 製 & 0.90 \\
\hline 紙・パ ル プ & 0.10 \\
\hline アルミニューム & 0.35 \\
\hline セx ン & $0.1,0.2$ \\
\hline アンモ $=$ ア & 0.62 \\
\hline
\end{tabular}

石炭ガス化

Koppers-Totzek

0.65

Synthane

0.46

飛行機・船船：0.28）から総括エクセルギー効率を求 めた。

鉱工業部門については, 計算の基礶となるデータが 十分なかったので, Reistad の行った米国に括ける同 部門の総括エクセルギー効率の值を用いた。米国と日 本の鉣工業部門の産業構造は大略においては類似して いるので, わが国のエクセルギー消費の中での鉱工業 部門の消費構成を把握する目的では, この 值を用いてもかまわないであろら。

以上の手覑で求めた各エネルギー消費部 門の総括エクセルギー効率を表 3 に示す。 また，これらのデータに基ついて作成し たわが国に杪けるエクセルギーの流れを 図6 に示す。

廃棄エクセルギーをエネルギー消費部門 別に大きい方から並べてみると，鉱工業， 発電, 運輸, 民生の順になって扣り, 特に鉱工業部門 からのエクセルギーロスが大きい。これはわが国の最 終需要エネルギー消費に占める鉱工業の割合が大きい
ことから当然の結果と言えよう。な拉米国 の場合，図 5 からわかるよらに，鉱工業部 門からのエクセルギーロスは最も少ない。 また図 3 のわが国のエネルギーの流れ図で は, 有用エネルギーのロスは発電和よび運 輸部門が最も多く, 鉣工業部門のロスはそ の約半分であった。

以上を要約すると，わが国の省エネルギ 一対策の基本課題は，鉣工業部門および発 電部門で廃棄された潜在的なエネルギー* を有効に利用することである。将来さらに 鉱工業部門に和けるエネルギーの需要叔よ び電力需要が増加し, 全エネルギー需要に 占める比率が大きくなることが予想されており ${ }^{10)}$, 鉱 工業部門に打けるエネルギー消費機器および発電シス テムの（エクセルギー）効率がかなり改善されないか ぎりむしろ現在よりも有効エネルギーの廃棄の割合 は増加するであろら。言換えれば総合エクセルギー効 率は現在よりも悪くなる。なお参考までに, 鉣工業部 門に打ける幾つかの工業プロセスのエクセルギー効率 を表 4 に揭げておく积13)14)。

\section{5. 石炭変換プロセスの役割}

前章では，特に石炭にとらわれることなく，わが国 におけるエネルギーの消費構造を把握するために一次 エネルギーの供給から最終需要に抢けるエネルギー消 費に至るまでのエネルギーの利用状況を見てきた。本 章では，石炭変換によるエネルギーがこのようなわが 国のエネルギー消費構造の中で，将来どのように位置 付けられるかを簡単にふれる。

石炭変換技術には, 直接燃焼, ガス化, 直接液化, 間接液化，乾留などがある。従って，それらのプロセ スから得られる生成物も多種多様である。図 7 は各種 石炭転換技術とその生成物の用途，最終需要に和忷る

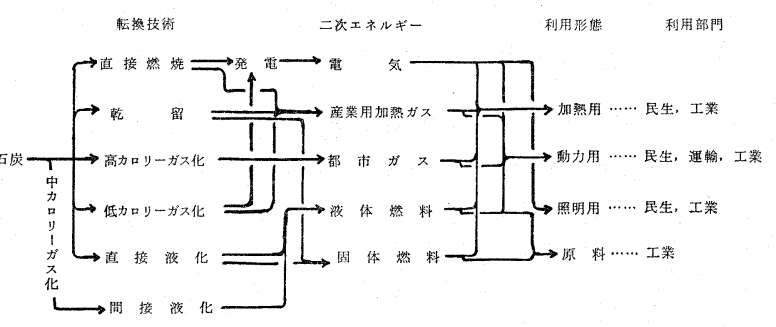

図 7 石炭利用におけるエネルギーの流れ

* エクセルギーのことを Potential (潜在) エネルギ 一と呼ぶことるある。 
利用形態とその消費部門をエネルギーの流れの中に位 置付けたものである。エネルギーの流れはわが国に拉 いて主として利用されるルートのみを示してある。た とえば, 石炭の直接液化から得られる固体燃料 (SRC) は米国では発電用に利用することを考えているが，わ が国の場合，その利用はおそらくないものとして図に は示していない。な特，各種石炭変換技術の詳しい説

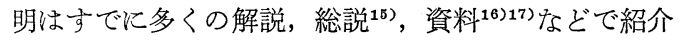
されているのでここでは割愛する。ただし，エネルギ 一有效利用の立場からは各種の具体的な石炭変換プロ セスについて次回以後必要に応じて取り上げ考察す る。

図7に見られるように，石炭は他の化石然料之同様 に適切な転換を行うことによって，すべての利用形態 で利用できる。電力として二次ェネルギーに変換した 場合, 加熱, 動力, 照明といった多くの形態で利用で きるのに対して他の二次ェネルギーに変換した場合, その用途は限られる。使って, 石炭の二次エネルギー の利用形態を石炭の需要面から見て大別すれば, 電力 用と非電力用となるであろう。これらの需要部門のう ら, 発電部門は量的に, また受入れ体制から見て最も 早期に需要量の大きなシェアーを受けもつことである ら。すでに前章までに指摘したように, 化石然料を原 料とした場合の発電システムに撢ける效率, さらに, 最終需要部門に和けるェネルギー変換機器の効率を考 えた場合, 発電による一次エネルギー变換から最終需 要消費に至るまでの総合効率は非常に低くなる。従っ て, 石岝資源の有効利用からみて, 発電システムに特 ける効率の向上は不可欠である。もし将来, 石炭火力 発電が大々的に利用されることになれば, 発電システ ムに叔ける数パー七ントの効率の向上は大きな石炭資 源の節約につながる。次回以後で詳しく述べるが，石 炭の低カロリーガス化による複合サイクル発電はその 効率向上の一方策であらう。

発電以外の石炭の利用として問題となるのは, 最終 需要の工業, 民生, 業務和よび運輸部門に対してどの ようなエネルギーの形で使用, 消費するかである。石 炭エネルギーの利用形態には, 気・固・液およびスラ リーの 4 つの形態が考光られるが, 気・液の形態, す なわち流体とするには固体の石炭を転換することが必 要となる。わが国においては，エネルギーシステムの ほとんどが，流体ェネルギーの使用を前提として供給 輸送システムから消費設備機器に至るまで定着してい る。その上, 燃料あるいは土ネルギーに対するユーザ 一の遙好は, 使いやすいクリーンな然料であるガス体
あるいは液体然料を指向しているのが現状である。従 って，石炭エネルギーを工業，民生，業務和よび運輸 にまで浸透させるためには，供給源において固体の石 炭からガス化あるいは液化の転換技術によって，ガス 体あるいは液体のエネルギーとすることが要求され る。また，このよらな方途を選べば，石炭エネルギー への転換移行の過渡期に抹いて, 石油系と石炭系の土 ネルギーの併用が可能であり, 消費部門の変革を必要 としない。しかし，一方，石炭の転換プロセスは比較 的効率が低く, さらに多額の建設費を要する転換設備 によってコスト高とならざるを得ない。従って, 非電 力用に対しては, 最終需要に拈ける利用形態および利 用部門を考えた上で適切な転換プロセスを選定すべき である。な特，このようなトータルシステムの中に括 ける石炭転換技術のエネルギー有効利用から捉えた考 察は最終回に行う予定である。

\section{文献}

1）エネルギー変換懇話会編 :「エネルギー工学総論」 第 5 章「効率とエクセルギー」, オーム社 (1979)

2) エネルギー変換懇話会編：「エネルギー利用工学」 第 1 章「エネルギー利用工学概論」, 第 2 章「エ ネルギー有効利用のための熱力学」, オーム社 (1980)

3) J.W.Gibbs, (1875); Collected Works-Vol. I, Yale Univ. Press, New Haven, 77 (1948)

4) J.Keenan, "Thermodynamics", John Wiley \& Son, New York (1941)

5) R. A. Gaggioli, Chem. Eng. Sci., 17, 523 (1962)

6) G. M. Reistad, ASME J. of Eng. for Power, 97, 429 (1975)

7) G.M. Reistad, A.C.S. Symposium Series, 122, 93 (1980)

8) A. Gardel, "Energy-Economy and Prospective”, Pergamon Press (1981)

9)「WAES レポート：世界ェネルギーの将来 19852000」日本 AES 機構訳, 共立出版 (1977)

10)「2000年のエネルギー構造」, 日本産業技術振興協 会 (1977)

11) E. Cook, Scientific American, 225, 135 (Sept. 1971)

12) R.A. Gaggioli, Paper presented at AIChE Annual Meeting, Chicago, (Nov. 1980)

13) R. A. Gaggioli, P.J.Petit, Chemtech., 496, (Aug. 1977) 
14) L.T.Fan, J.H.Shieh, Energy, 5, 955 (1980)

15）たとえば,「特集 : 石炭液化技術の開発」, 化学工 学, 44, №.9 (1981)

16）「石炭資源開発・液化技術総合資料集」，サイエン
スフォーラム社 (1981)

17)「石炭利用・発電プラント技術総合資料集」, サイ エンスフォーラム社 (1980)

\title{
Evaluation of Coal Conversion Processes from an Energy Efficient Use Viewpoint ( I )
}

\author{
Naonori NISHIDA*, Masaru IsHIDA** \\ $\left(\begin{array}{l}\text { * Department of Management Science, Science University of Tokyo } \\ * \text { Research Laboratory of Resources Utilization, Tokyo Institute of } \\ \text { Technology }\end{array}\right)$
}

SYNOPSIS : - In this series, we attempt to evaluate various coal conversion processes from an energy efficient use viewpoint, and also clarify how and where each conversion process has to be utilized in the total energy network of Japan.

In this paper, various energy chains, which produce heat and mechanical work from different primary energies, are compared by two efficiencies of an energy-conversion process, i. e., thermal and exergy efficiencies.

To see how primary energies were consumed in the overall energy flow in Japan, an exergy flow diagram for Japan in 1975 was presented and compared with its for the U.S. by Reistad. A typical difference in the wasting of exergy between Japan and the U.S. was that the largest contributor to the wasting of exergy in Japan was industrial sector, while in the U.S. the industrial sector was the lowest. Finally, a coal energy chain is illustrated, in which coal is converted into different secondary energies through various coal conversion processes and they are consumed in the end-uses. The future coal energy chain in Japan was briefly discussed. 